\title{
lan Nairn, Townscape and the Campaign Against Subtopia
}

\author{
Lorenza Pavesi \\ Designer, MSc in History and Theory (University of São Paulo in \\ São Carlos, Brazil), PhD candidate in Urban Planning (University \\ of São Paulo), and visiting researcher in CRP Cal Poly (2013-14)
}

The Townscape movement had a strong influence in the British academic and professional circles. lan Nairn was one of its early and most important advocates, particularly due to his writings for the influencial magazine Architectural Review and his TV shows. In this article based on her master's thesis, Lorenza Pavesi discusses Nairn's importance for planning and urban design. Lorenza is currently a visiting researcher at CPR, studying the diffusion of Townscape principles in the US, Italy, and Brazil towards her PhD with the University of São Paulo, Brazil.

In n June 1955, the English periodical The Architectural Review published a special edition called Outrage, authored by young critic lan Douglas Nairn (1930-1983) and which had a profound impact on the post-war reconstruction debate. This article analyses lan Nairn's involvement with Townscape, the urban design methodology articulated by the magazine Architectural Review -or simply the AR-from 1947. By exploring the historical context of post war Great Britain as well as the specific cultural climate within the magazine, this article aims to

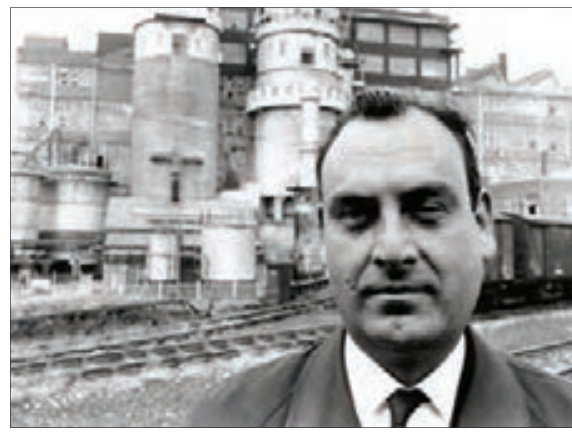

Figure 1: lan Nairn, an outraged and outspoken critic of mediocre British planning and design. (source: BBC, London) assess Nairn's largely underestimated contribution to promote Townscape ideals in Great Britain and other countries.

As David Harvey (1989: 68-69) notes, the political, economic and social difficulties faced by advanced capitalist countries in the wake of World War II required policies that addressed questions of full employment, decent housing and social provision. While strategies differed in the extent of war-time destruction, the acceptable degree of centralization in political control or the level of commitment to state welfarism, the general trend was to consider the war-time experience of mass production and planning as means to launch a vast program of reconstruction and reorganization in which the renewal and re-shaping of the urban fabric became a crucial element.

In the case of Britain, the solution involved the implementation of a rigorous town and country planning legislation and

Note: This article is based on the author's master's dissertation; see Pavesi (2011). The author is grateful to the Fundação de Amparo a Pesquisa do Estado de São Paulo (FAPESP) for supporting her research.

the adoption of one of the world's largest planning initiatives: the development of new towns inspired by Ebenezer Howard's garden cities.' In 1937, Neville Chamberlain (1869-1940), an important advocate of garden cities, became Prime Minister and one of his first initiatives was the formation of the Royal Commission on the Distribution of the Industrial Population to study the causes and effects of the geographical concentration of industries and population in cities, and to prescribe measures to deal with the problems arising from it. Published in 1942, the resulting Barlow Report was the first national survey on the effects of the Industrial Revolution, raised the problem of large cities as a public issue for the first time, recommended the decentralization of congested urban areas, and called for national planning. These early efforts led to the New Towns Act of 1946 and to the Town and Country Planning Act of 1947 that established a land use control system in Britain.

Historiography seems to agree that, in Britain, the Modern Movement involved a political as well as a moral battle against a strong reluctance and skepticism of the general public and the popular press. Alan Powers (2007: 9) reminds us that the British have always been considered cautious, nostalgic and not willing to cast aside pre-modern methods of ordering the built environment. However, during the interwar years, the garden city model, which represented an important British

\footnotetext{
${ }^{1}$ Howard (1850-1928) authored the influential book Garden Cities of Tomorrow (1988) and founded the Garden Cities Association in 1899 to promote those ideals. In 1941 the association became the Town and Country Association (TCPA) and expanded its charter to promote housing, planning, and community development.
} 
contribution, attracted the criticism of those who considered it the cause of suburban sprawl and of an increasing individualism (Powers, 2007: 63-64).

In fact, despite the slow pace of reconstruction, in the 1950s a large part of the British new towns had been developed enough to allow an evaluation and the criticism surfaced mainly in the pages of $A R$ which decried their lack of urbanity and "provincial torpor". In July 1953 the AR published the articles "Prairie Planning in the New Towns" by Gordon Cullen and "The failure of the New Towns" by J.M. Richards which both highlighted the impact of a low-density approach. To lan Nairn (1956: 366) and other Townscape advocates it became clear that low density suburbs and new towns had become over the years the "mainstay of planning policies".

In Britain, the post-war reconstruction debate took place mainly within MARS (Modern Architecture Research Group), in schools of architecture and in several journals. Among these, the AR plays an important role for maintaining during this period, a clearly defined editorial point of view and for stimulating a debate that went beyond the strict interests of the profession. The AR solid support for Modernism was in fact outweighed by other interests and, during the war, the magazine published important articles on the history of architecture, popular taste, the tradition of nineteenth-century utilitarian construction and covered the architectural and urban development in countries not directly affected by the war, such as Brazil or Canada, but also kept a watchful eye on the United States and Sweden (Bullock, 2002: 29-30).

In its search for new solutions, the London based magazine encouraged planners and architects to reconcile Modernism with local traditions. To the editors, the possibility of applying the composition principles of the Picturesque aesthetic ideal led to the revival of an English tradition, and therefore to a British identity in architecture and town planning (Bullock, 2002: 5). It was important for the magazine to try to correct the perception of the Picturesque as a historicist theory and to link it to modernist functionalism, which the editors do by publishing several essays, including "The English Planning Tradition in the City" ${ }^{\prime 2}$ where the Picturesque is described not as an enemy but as a "close relative".

The first $A R$ issue was launched in 1896 and during the 1920 s and 1930s the magazine, under the command of Hubert de Cronin Hastings (1902-1986), one of the most iconic personalities in the history of the AR, gave support to many architects and designers who came to Britain. From the end of World War II until 1971, the editorial board was basically composed of Hastings, the German art historian Nikolaus Pevsner (1902-1983) and the critic and historian J.M. Richards (1907-1992). Commentators such as lan Nairn, complemented the work of the editorial board.

${ }^{2}$ Written by AR's editors, "The English Planning Tradition in the city" was published in The Architectural Review vol. 97, p.165-176, June 1945,
The article "Exterior Furnishing or Sharawaggi: the Art of Making Urban Landscape" by AR's editors (Hastings and Pevsner with, perhaps, the participation of Nairn), published in 1944, is regarded as one of the most important articles that anticipated the launching of Townscape principles (Figure 2). This article defines the Picturesque as the ability to visually reconcile, in any city plan, seemingly incompatible elements. The term Sharawadgi was first used by Sir William Temple (1628-99) in his book Upon the Gardens of Epicurus (1685) to describe a way of planting without an apparent order. The term was popularized in 18th England to describe irregularity, asymmetry and surprise through a "graceful disorder".

Both Hastings and Pevsner regaded the Picturesque doctrine as crucial in order to use the English tradition to obtain a more compassionate and human version of Modernism as well as to awake the sensibility of readers and authorities in the postwar rebuilding efforts. As noted by Alan Powers (2007: 10-11), Pevsner believed that the British contribution to urban planning was to be found in the Picturesque due to its foundation on human sensations and its sensitivity to natural processes, and therefore not in formal Modernism.

Hastings' philosophy was adopted by several authors who sought new ways to look at the development of cities and a survey of AR from 1930 to 1980 results in approximately 1,400 articles related to Townscape principles and written by about 200 authors, many of which are absent in the historiography of the period (Macarthur, 2007, p.198).

The principles of the Townscape visual philosophy have their most important demonstration on the occasion of the Festival of Britain, a national exhibition which opened in May 1951 and which aimed to promote quality projects for the reconstruction of cities that were still damaged after the war. Young architect and interior decorator Hugh Casson (1910-1999) was nominated

Figure 2: Illustration from "Exterior Furnishing or Sharawaggi: The Art of Making Urban Landscape", The Architectural Review, January 1944.

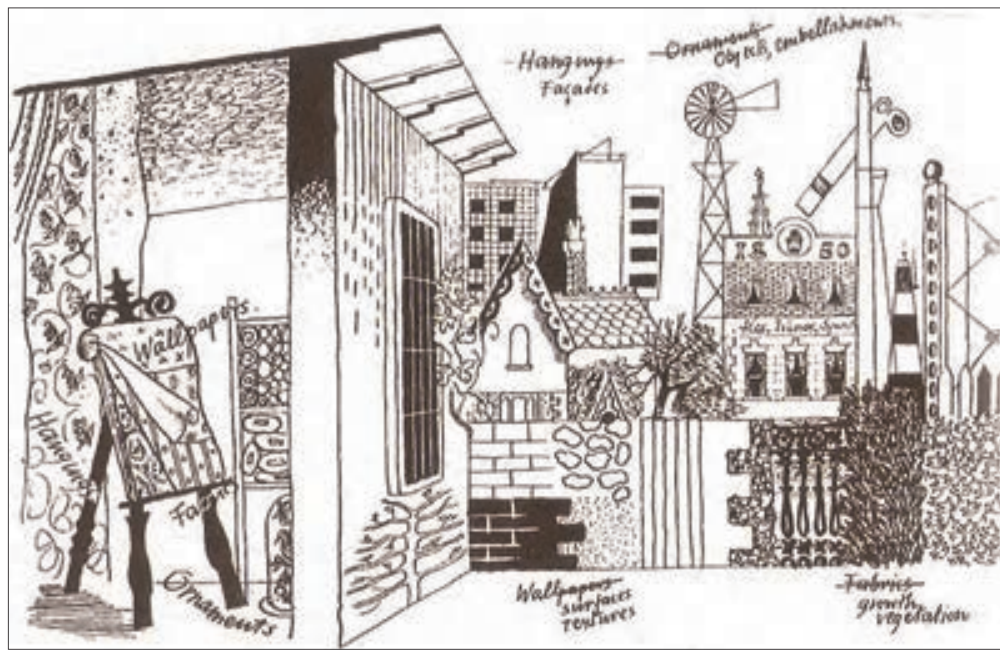


Nairn's arrival, who was then only 25 years old, to the magazine's editorial board in 1955 coincides with the peak of $A R$ criticism on post-war reconstruction and the state of the urban scene and Nairn found in the AR an environment that favored an architectural approach informed by climate, materials and specific qualities of the genius loci, the spirit of place.

AR special edition Outrage, published in June 1955, originated from observations made by Gordon Cullen and lan Nairn during a journey from the city of Southampton in southern England to Scotland border. At the end of this journey, they concluded:

"the end of Southampton looks like the beginning of Carlisle and the parts in between look like the end of Carlisle or the beginning of Southampton" (Nairn, 1955: 365).

In Outrage Nairn advocates for the protection of "characteristic places" as important to the survival of a "characteristic English consciousness" and called the characterless landscape, neither country nor town, Subtopia (Figures 4 \& 5). This neologism was used to describe the dilution of landscape types creating what these publications perceived as a hybrid territory generated by planning who despised the individuality of each place. Subtopia, according, to Nairn represented:

"... a prophecy of doom; the prophecy that if what is called development is allowed to multiply at the present rate, then by the end of the century Great Britain will consist of isolated oases of preserved monuments in a desert of wire, concrete roads, cosy plots and bungalows. There will be no real distinction between town and country [...] it is a morbid condition that spreads both ways from suburbia, out into the country, and back into the devitalized hearts of towns...subtopia is the world of universal low-density mess" (Nairn, 1955)

Subtopia represented therefore more than a physical reality but a "mass psychosis rooted in the fantastic acceptance of mediocrity". The planning offensive was started in a mood of idealism which assumed two things: that rules would be used flexibly and intelligently, and that England was of unlimited size. This last, single, radical miscalculation gave rise to the whole philosophy of dispersal - expanded towns, New Towns and every house with a garden, which is now the mainstay of official planning policy: an admirable idea in vacuo, and implemented in perfect good faith, but condemned before it started by our coast-to-coast dimensions (Nairn, 1955: 367).

We remind that five years earlier, in the AR, the article "Manmade America - Chaos or Control?" edited by Christopher Tunnard, at the time Town Planning professor at the University of Yale, described a similar journey through the United States where the uncontrolled development had damaged a large part of the rural scenery along paths that would become later interstate on highways. In Outrage Nairn writes:

"In 1950 the Review traced this rake's progress, both planned and unplanned, in some of its manifestations in

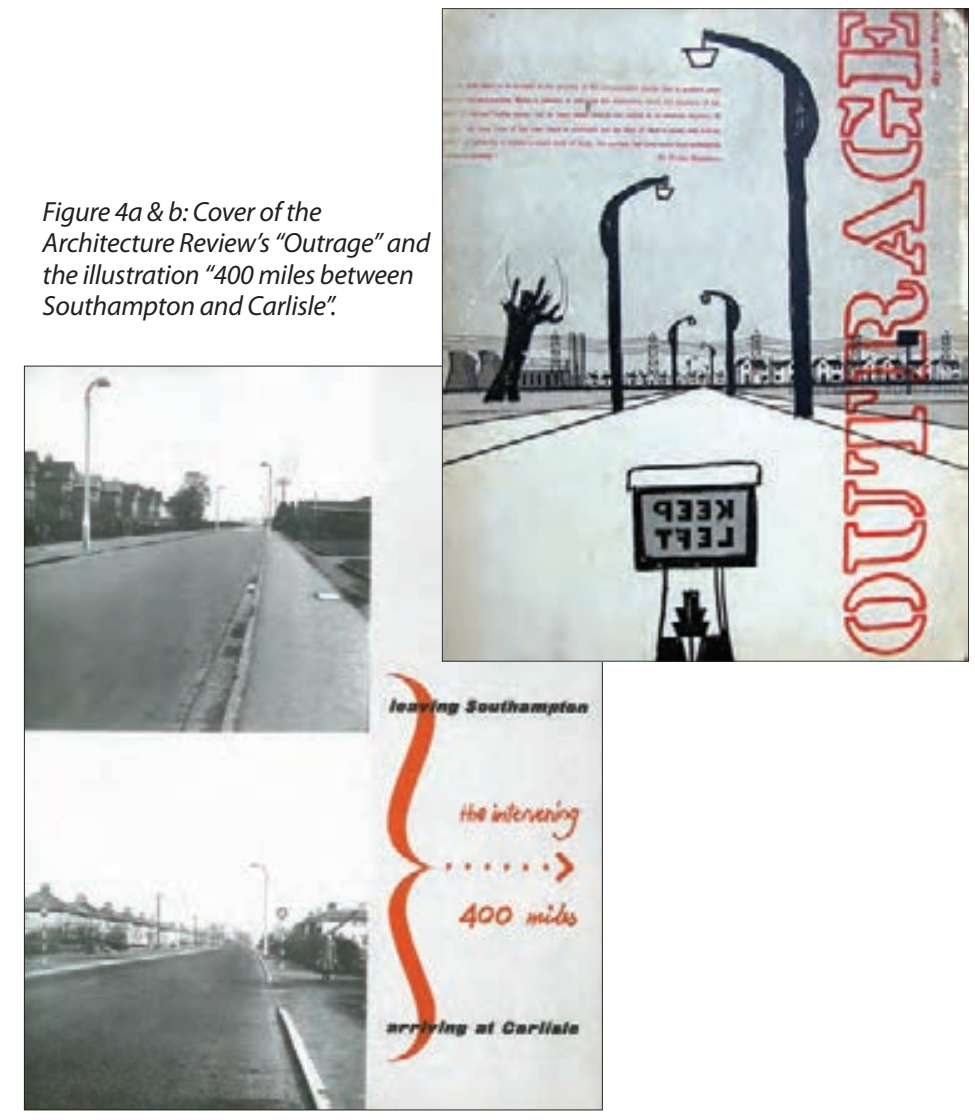

the U.S., a piece of research which drew from some of its American readers subdued applause but raised the blood pressure alarmingly in others. Unnecessarily, since the fact that we are all in this thing together, first as the victims and then, in varying degrees, as the offenders, is the first thing we have to know about it. Here the Review (as it promised then) turns the searchlight upon this country" (Nairn, 1955: 368).

The special edition Outrage, as well as a special column with the same name published in the $A R$, constituted a serious and important research on the problems that planning could not solve, or even encouraged, and on the damage caused to the urban and rural landscape in the British post-war period, and served therefore to emphasize that Europe was not immune to the attacks to the landscape denounced by Tunnard.

Gordon Cullen (then Assistant Art Director of the magazine) presented sequences of photos and drawings of urban equipment, electrical wiring, poorly pruned trees and advertising; the issue cover illustrates in a very evocative way, the urban chaos, created, according to Nairn, by traffic engineers and public officials. As stated by Nairn (1955, p.366), the $A R$ 's concern was mainly visual and the magazine, in fact, was known for the visual experience afforded by its pages allowing images to reach an audience whose experience of a 
printed visual culture was still quite limited. In addition to the carefully prepared photographs of well-known authors, The $A R$ also featured numerous photographs captured by amateurs and members of the magazine staff, including lan Nairn. These informal photographs eventually became important tools of architectural journalism, especially after the war, and were just as controversial as those taken by professional photographers.

With the essay "Outrage and righteous indignation: ideology and imagery of suburbia", authors Gold and Gold intend to demonstrate how architects and architecture critics contributed, consciously or not, to build a negative image of the suburbs, and describe Outrage as a "stridently antisuburban" and manipulative work (Boal et al eds., 1989: 164) that contributed through short texts enhanced by a wide repertoire of illustrations and photographs, to the "already extensive anti-suburb literature of those years" (Figure 5).

Outrage concludes with a manifesto for the layman which encouraged the Englishman to take initiatives for the protection of the landscape and to take action against the expansion of subtopia and the impositions of the "tyrannical town planner". The triumph of Outrage prompted the $A R$ to set up a "CounterAttack Bureau" in order to handle the enquiries from architects, planners and ordinary citizens and which consisted in a sort of task force or, in the words of the editors, in a "service to monitor and guide the good visual character of England".

The $A R$ also launched a monthly column called "CounterAttack" which monitored specific cases submitted by readers who, in this way, became an active part of the process. As suggested by Pousin (2007), this monitoring was offered by lan Nairn and Gordon Cullen who through this consultancy, promoted an attitude that favored both the old - preserving, for example, the fabric of a city - as the new - by managing public spaces and seeking creative solutions, according to the editors, independent from existing doctrines.

Figure 5: The kind of informal photograph printed in the pages of AR special issue "Outrage" (1955, p.383) and mentioned by Gold \& Gold and others. (Photo: lan Nairn)

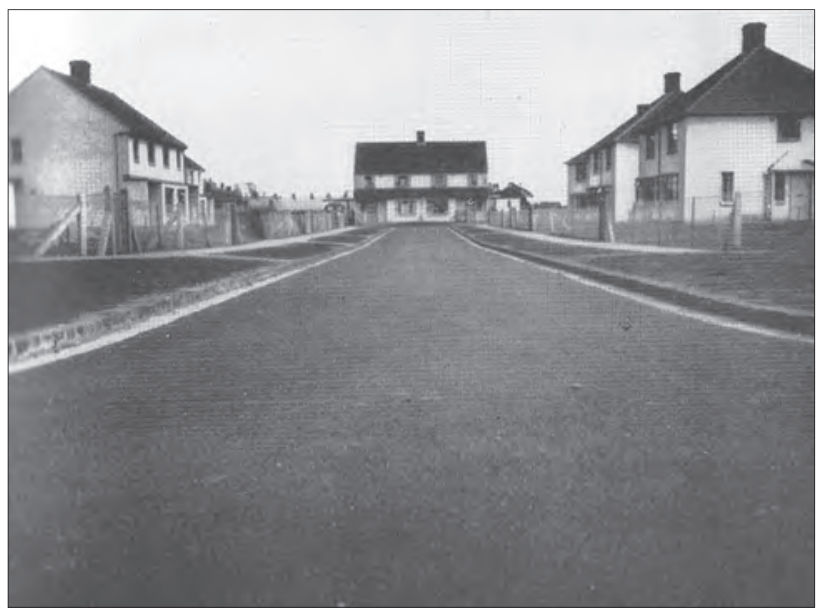

The impact of Outrage, described by Hugh Casson as a "hard blow to the self-esteem of architects and planners ${ }^{\prime \prime}$, prepared the ground for the launch, in December 1956, of another memorable special edition: Counter-Attack against Subtopia edited by lan Nairn. In this issue the critique on the suburbs, the New Towns and the legacy of the garden city is further developed and explored in more depth.

Unsurprisingly, an image of Los Angeles opens this edition (Figure 6). The Californian city, in fact, was considered by the $A R$ editors and other theorists the worst example of suburban sprawl. In their view its low density represented the crisis of the contemporary city, a vision that was later contested by Reyner Banham $^{10}$, a renowned British architecture historian who joined the AR editorial board in 1959 and remained until 1964, in his book Los Angeles: the architecture of four ecologies (1971). According to Banham, Los Angeles threatened "the intellectual repose and professional livelihood" of many architects, artists, planners, and environmentalists because it broke the rules of urban design that they promulgated. Banham challenged the belief held by theorists such as Jane Jacobs, the Team Ten and the $A R$ editors that certain densities and certain physical forms were essential to the working of a great city.

But in Counter-Attack against Suptopia lan Nairn and other authors were still insisting on the issue of density: sixteen years after the publication of the Barlow Report, the mission to decentralize and redistribute the population had practically been achieved, but the concept in which density calculations were based, in their view, needed to be reworked.

Both Outrage and Counter-Attack against Subtopia attracted widespread interest in the United States and numerous letters from individuals and American associations commenting and identifying with the issues raised by Nairn reached (and further encouraged) the AR editorial committee.

Among the enthusiasts was William H. Whyte who, in 1958, asks Nairn and Cullen to contribute with a photo essay and drawings to an article by Jane Jacobs called "Downtown is for people" in conclusion to the Fortune magazine edition Exploding Metropolis (published as a book in 1958). Undeniably Nairn represents a significant link between the countries where the debate around the damage (aesthetic, economic and environmental) of suburban sprawl was more heated: Britain and the United States and is also the anti-suburb discourse that caused the alliance of AR editors with the influential American author Jane Jacobs which declared herself an "avid Townscape follower". ${ }^{9}$

In 1961, Jacobs publishes her influencial book Death and Life of Great American Cities, defined by David Harvey (1989: 73) as"one

\footnotetext{
${ }^{7}$ Casson, H. "Outrageous Postscript" in Journal of the Town Planning Institute. July-August 1956, p. 187-192.

${ }^{8}$ Banham was Pevsner's PhD student and became a renowned architectural historian himself. He the AR editorial board in 1959 and was the assistant executive editor until 1964.
} 
of the first, most articulate and most influential antimodernists treatises". In his review of the book, Hastings (under the pseudonym Ivor de Wolfe) declares:

"Now comes a warm but high wind across the Atlantic and (one hopes and believes) a hot handshake for the lan Nairns, Gordon Cullens and Kenneth Brownes of this continent in the shape of a book which is a must for all who believe the urban consequences of those odd bedfellows, Ebenezer Howard and Le Corbusier, to be the spawn of the devil working through his chosen vessels."10

Isaacs (2000) notes how, although Jacobs didn't discuss the pictorial aspect of a city directly, her comments and sketches implied some similarity to the sensitivities of Gordon Cullen. Between 1955 and 1965, the Rockefeller Foundation responded to the post-war housing crisis by funding research projects on Urban Design. Among the researchers sponsored by the Foundation were Kevin Lynch and Gyorgy Kepes whose research on the perception of urban form gave rise to the book The Image of the City, published in 1960, as well as Jane Jacobs, Christopher Alexander, Christopher Tunnard, Ian McHarg, lan Nairn and others (Laurence, 2006).

The scholarship that lan Nairn received from the Rockefeller Foundation allowed him to travel across the United States for a year (1959-1960). This journey resulted in the book The American Landscape: a critical view published in 1965 where Nairn records his impressions about the character of the American landscape which he defines as a "chaos of nonrelation". In this book Nairn hopes that one day the American landscape could achieve a new unity through the use of Townscape which he defined as "the art of relating objects in an organic and sensitive way". Again Nairn alerts to the effects of the landscape on the mind and reminds readers that, by giving identity to places, Townscape gives identity also to people (1965: 3). In The American Landscape, Nairn comments on the lack of identity of the Levittowns, the large suburban communities with its dwelling, almost identical to each other. The Levittowns suburbs, the first mass-produced communities, became in fact a prototype and similar communities were built throughout the country after World War II. Nairn compared the Levittowns with the quiet town of Ysleta (now in Texas):

"In Ysleta one can say"I'm here in X. Outside is Y, somewhere different. In Levittown all he can usually say is "Where the hell am I?" (Nairn, 1965: 45)

A review of Nairn's book published by The New York Times in

\footnotetext{
${ }^{10}$ Jacobs made this comment in a letter to Hastings dated march 1964, kept in Priscilla Hastings personal archive. See Erten, 2004: 102.

${ }^{11}$ In "The Death and Life of American Citizens", de Wolfe's review of Jane Jacobs's The Death and Life of Great American Cities (The Architectural Review, February 1963, n.792, vol.133, p.91-93). The relationship between Nairn and Jacobs is further strengthened during her first visit to Europe in 1967 (see: Nairn, I. Cities 'strangled by the planners'. The Observer, 12 February 1967: 12).
}

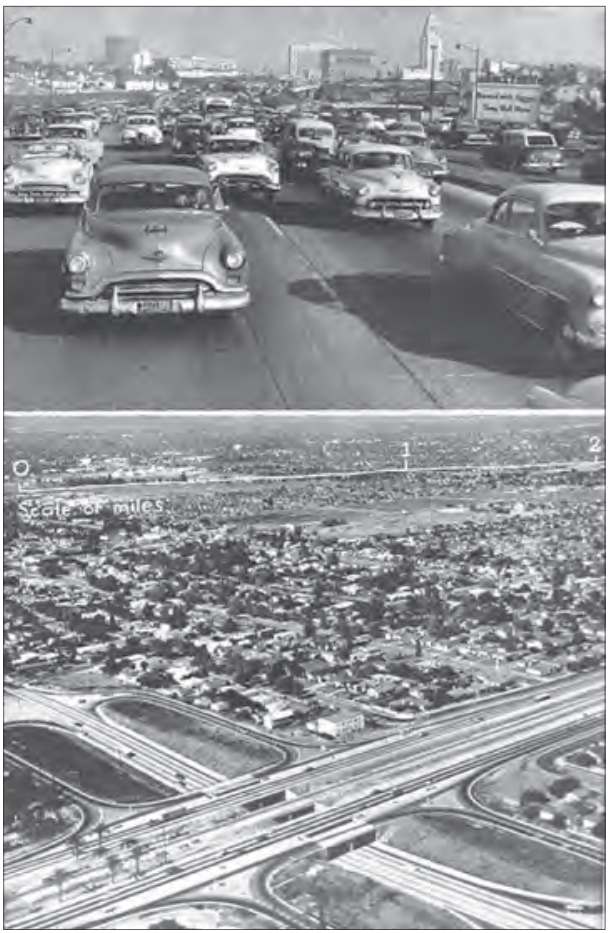

Figure 6: Views of Los Angeles in Counter-Attack Against Subtopia (Nairn, 1956: 354).

1965 started by explaining to readers that the art of Townscape, consists of two main factors: relationship and identity. ${ }^{12}$ According to the review, relationship is to fit together the parts of a particular environment, and identity is the recognition and appreciation of the needs and specific qualities that make one place different from another. Although the review was very positive, it objects to some of Nairn's negative comments such as against the downtown redevelopment plan and pedestrian mall for Kalamazoo, Michigan by Austrian émigré Victor Gruen (1903-1980). Although by then shopping centers had become the commercial cores of post-war suburbs, Gruen -who is considered the father of the modern shopping centerdesigned the Kalamazoo Mall as one of the first shopping centers for pedestrians within a city and represented one of the first attempts to revitalize cities against the growing suburbanization. Nairn, however, regretted that designers of this type of center, even with the best intentions, tended to simply throw all elements in the same space.

Interestingly, in the context of the circulation of planning ideas from Europe to the United States, Victor Gruen is one of the personalities whose career is also significant. Although he was not directly associated with Townscape, his architectural and urban production gained, during the 1950s and 1960s, high visibility and was inevitably exposed to the scrutiny of theorists and advocates of Townscape that, as we saw, were very

\footnotetext{
${ }^{12}$ Andrews, W. "Townscape: a New Name for a New Art" in The New York Times, 7 March 1965.
} 
interested in the suburbanization process in the United States. Gruen also criticized the "anti-city" and in his book The Heart of Our Cities: the urban crisis: diagnosis and cure (1964) he wrote: "If we do not want the city to be destroyed, if we do not want Anti-City to bury us, we have to prepare for an all-out counterattack" (Gruen, 1964), a statement that, in our opinion, echoes the warnings of the AR special editions of previous years.

Nairn continues this critique, commenting on the creation of Strøget, in Copenhagen, Denmark, according to him, a genuinely successful pedestrian zone: "everyone is obsessed with pedestrian precincts these days", writes Nairn, "the 1960s average town planner thinks that it's enough to just separate people from cars for the city to become glorious like Venice". This simple vision could, according to Nairn, do more harm than good and he invites all planners to see how the Danes were dealing with Strøget. Nairn concludes that it did not make sense to take the transit off a street without being sure that it would become "splendid" without it.

Throughout his career as a critic and journalist, Nairn provides countless examples of the Townscape approach and some terms coined by Gordon Cullen in his book Townscape will also appear in articles written by Nairn in major English newspapers during the 1960s and the 1970s. Nairn's style is undoubtedly vigorous, energetic and appealing and he is able, in our opinion, to convey urgency more effectively than other promoters of Townscape. He was a skilled writer having authored numerous

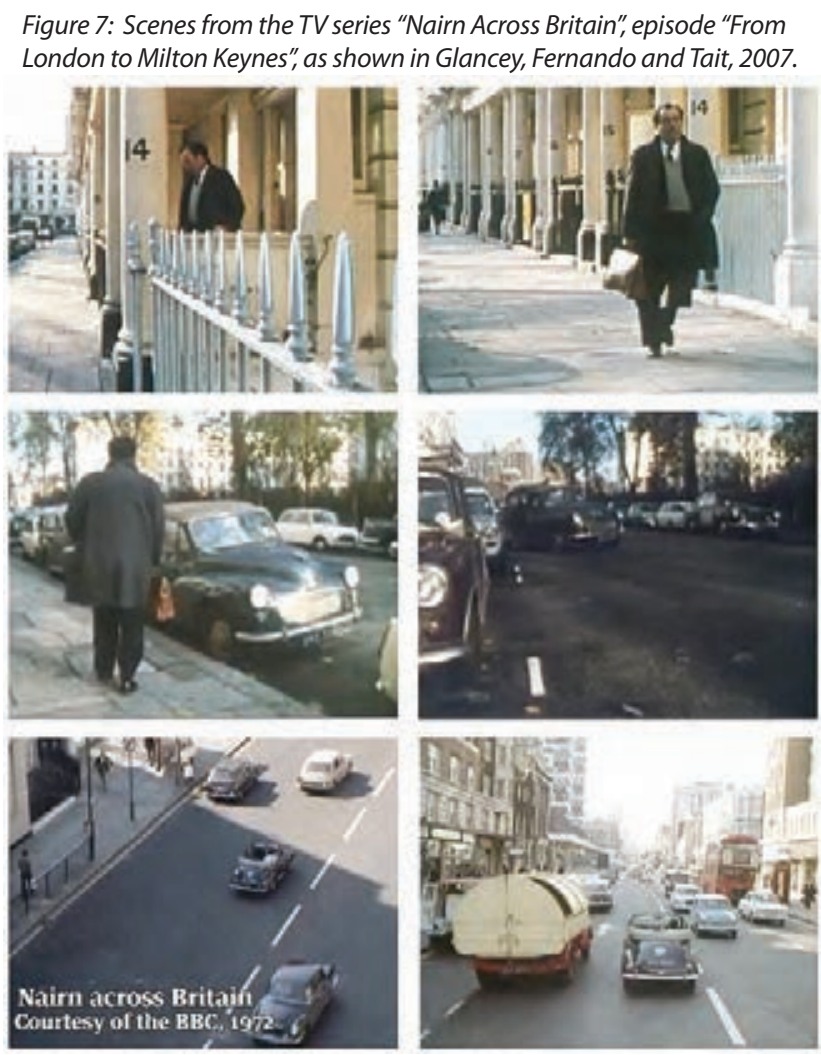

books, guides and pamphlets, and contributed to Buildings of England, the series of guides conceived by Nikolaus Pevsner, with the volumes on Surrey (1962) and Sussex (1965). Perhaps Nairn's most controversial texts were published in English newspapers, and his growing frustration culminates in a long article "Stop the Architects Now" in The Observer newspaper, where he accuses architects and planners of "stamping over the landscape in jackboots, the boasted trademark of Le Corbusier, that arch-priest of arrogance", what represented a further step in challenging Modern Movement urban policies. ${ }^{13}$

In this invective Nairn claims that the character of a place cannot be obtained by experts alone but by teams where all members have equal importance. He also accuses architects who, in his opinion, had been taught for years to regard themselves as "mini Mieses" and who had minimum contact with the site. According to Nairn, architects and planners were treated by the public in general, with contempt, they saw the architect as "a wet kind of nuisance, eternally fingering his bow-tie on the edge of real life" and the planner as one of the "dreariest inhabitants of a dreary local government structure".

As well as Nairn's talent as critic and polemicist, Graham King (2006) stresses his versatility, noting that he was the first and probably the only commentator to have exercised his critical skills in specialized magazines, books, newspapers and even television.

But to what extent Townscape could be said to have influenced the debate on the post-war reconstruction? According to Erten (2004: 294), resonances of AR campaigns are still present in several architectural discourses, Townscape was the most successful of its campaign, and today the book Townscape by Gordon Cullen is one of the canonical texts for urban design although distanced from the neo-romanticist ideology that originated it. Urban interventions and gradual development of high density and mixed use have replaced the 1960s urban renewal removals and are now commonly accepted, and Townscape principles were incorporated by New Urbanism in its advocacy of compact cities and critique of suburbia and zoning.

Urban regeneration programs and the global competition between cities have prioritized sustainability and the quality of urban design in contemporary public policies. This establishes a certain continuity with the past and the theories that advocated a return to the city urging us to retrace the history of urban design and examine the political and economic forces that molded them as well as their impact on the way we see the city and act upon it. From this point of view Erten (2004: 289-290) reminds us that Townscape's resistance against decentralization and its goals to keep the city compact and dense followed the

\footnotetext{
${ }^{13}$ Nairn, I. "Stop The Architects Now" in The Observer (Weekend Review) 13 February 1966, p.21.

${ }^{14}$ King, G. "Ian Nairn: the Missing Art of Townscape" in Urban Design Quarterly [online]. Issue 59, July 1996. URL: http://www.arch.mcgill.ca/ prof/sijpkes/arch374/winter2001/b_king.html. Accessed: 12.09.2009.
} 
ethical imperative to preserve the resources that fueled the city. This meant to preserve the livelihoods of those who cultivated these resources and to unterstand the landscape as a means to rehabilitate citizens.

lan Nairn emerged as a key interlocutor in the debate on the physical quality of planning and design, and the importance of the Townscape theory. Nairn's travels helped to spread this debate, and were not limited to the United States. He traveled again to the United States in 1967 as the Architecture Correspondent for the English newspaper The Observer and to Italy. There is also evidence that he travelled to Israel, France (a trip that resulted in the guide book Nairn's Paris), Switzerland, Canada, Denmark and Australia, and maybe to other countries. In Italy some of his writings had a strong impact in the post-war reconstruction efforts when Italian were searching for solutions to for urban problems arising from the conflicts between the new and the old in the redevelopment of the historical centers damaged by World War II.

Not only Nairn's travels and international efforts reveal his belief in the usefulness of cultural exchanges between countries, but without a doubt were important for the export of Townscape theories outside of England. In fact, although historiography commonly regards the movement as a strictly British phenomenon, Townscape is connected to the lineage of urban design of authors such as Kevin Lynch, Christopher Alexander, Jane Jacobs, and even to Yoshinobu Ashihara in Japan.

There are numerous indications that Townscape was received, assimilated and incorporated into urban theories and practices -more or less successfully- what raises many questions that, in the author's opinion, should be further explored. As noted by Friedman (2010: 326), in the ambit of the circulation of ideas and experiences it is always important to identify interactions that generate creative and learning experiences that contribute and enhance the relevance of what is being exchanged, separating them from those that impose or copy an idea or practice, promoting it as a universal solution, and often leaving a legacy of failure and cynicism.

\section{References}

Boal, F. W.; Livingstone D. N. \& Kirk. W. (eds.). 1989. The Behavioural Environment: Essays in Reflection, application and reevaluation. London: Routledge.

Bullock, N. 2002. Building the Post-War World Modern Architecture and Reconstruction in Britain. London: Routledge.

Cullen, G. 1961. Townscape. London: Architectural Press.

Erten, E. 2004. Shaping "The Second Half Century": the Architectural Review, 1947-1971. Cambridge. PhD Dissertation in Architecture History and Theory. Department of Architecture, Massachusetts Institute of Technology (MIT).
Friedman, J. 2010. Crossing Borders: Do Planning Ideas Cross Borders? In P. Healey \& R. Upton (eds.) Crossing Borders: International Exchange and Planning Practices. Oxon, UK: Routledge.

Glancey, J; Fernando, S. \& Tait, M. 2007. Outrage Revisited. A documentary for The Guardian newspaper. At <http://www. guardian.co.uk/artanddesign/video/2010/jun/07/outragerevisited-milton-keynes-architecture?INTCMP=ILCNETT XT3486>. Accessed: 6/8/2010.

Gruen, V. 1964. The Heart of Our Cities: the urban crisis: diagnosis and cure. New York: Simon and Schuster.

Harvey, D. 1989. The Condition of Postmodernity: An Enquiry Into the Origins of Cultural Change. London: John Wiley.

Healey, P. Upton, R. eds. 2010. Crossing Borders: International Exchange and Planning Practices. Oxon, UK: Routledge.

Isaacs, R. 2000. The Urban Picturesque: an aesthetic experience of Urban Pedestrian Places. In Journal of Urban Design vol. 5 n. $2,145-180$.

King, G. 1996. Ian Nairn: the Missing Art of Townscape. In Urban Design Quarterly 591996. At <http://www.arch.mcgill.ca/ prof/sijpkes/arch374/winter2001/b_king.html. Accessed: 9/ $12 / 2009$.

Macarthur, J. 2007. The Picturesque: Architecture, Disgust and other irregularities. London: Routledge.

Laurence, P. L. 2006. The death and life of urban design: Jane Jacobs, the Rockefeller Foundation and the New Research in Urbanism, 1995-1965. In Journal of Urban Design vol.11 n.2, p.145-172.

Mumford, E. 2002. The CIAM Discourse on Urbanism: 1928 1960. Cambridge, MA: MIT Press.

Nairn, I. 1955. Outrage. London: Architectural Press. 1957. Counter Attack Against Subtopia. London: Architectural Press, 1957.

1965. The American Landscape: a Critical View. London: Random House.

Pavesi, L. 2011. Ian Nairn, Subtopia e Townscape. MSc. in Architecture Dissertation. School of Engineering, University of São Paulo at São Carlos.

Powers, A. 2007. Britain, Modern architectures in history. London: Reaktion Books.

Pousin, F. 2007. Du townscape au 'paysage urbain', circulation d'un modèle rhétorique mobilisateur. In Strates, Matériaux pour la Recherche en Sciences Sociales 13 - Paysage urbain: genèse, représentations, enjeux contemporains. At $<$ http://strates.revues.org/document5003.html>. Accessed: $7 / 17 / 2009$.

Webster, R. ed. 2000. Expanding Suburbia: Reviewing Suburban Narratives. New York: Berghahn Books. 